Економічні науки: збірник наукових праць Луцького національного технічного університету. Серія "Регіональна економіка". Випуск 18 (71). Редкол.: відп. ред. д.е.н., професор Л.Л. Ковальська. Луцьк: ІВВ Луцьккого НТУ, 2021. 278 с.

УДК 334.012.42:338

Смаль Б.А, аспірант

Луцький національний технічний університет

\title{
РЕГІОНАЛЬНІ АСПЕКТИ РОЗВИТКУ КОНКУРЕНТНИХ ПЕРЕВАГ ІНДУСТРІЇ ГОСТИННОСТІ
}

В статті досліджено регіональні засади розвитку готельного господарства в Україні. Визначено зміст та значення готельного господарства у структурі регіонального розвитку індустрії гостинності. Проаналізовано міжнародний досвід розвитку готельного господарства. Проведено аналіз розвитку готельного господарства в динаміці та у регіональному розрізі. Систематизовано конкурентні переваги готельного господарства в регіонах України. Запропоновано напрями розвитку конкурентних переваг готельного господарства.

Ключові слова: конкурентні переваги, готельне господарство, індустрія гостинності.

Smal B.

\section{REGIONAL ASPECTS OF DEVELOPMENT OF COMPETITIVE ADVANTAGES OF THE HOSPITALITY INDUSTRY}

The hotel industry plays an important role in the development of the region, stimulating its socio-economic development, increasing competitive advantages, forming a positive image of tourists and guests of the region, providing jobs to the local population and more. All this is possible under the condition of coordinated work of all participants in the development of the hotel industry in the region and the presence of a clear and well-thought-out action plan given the presence of modern negative factors. Given the subject of our study, we consider it appropriate to consider the international experience of organization and development of the hotel industry and to determine the content and regulatory support of the studied processes.

The role of the hotel industry in the structure of regional development of the hospitality industry is generalized and determined. It is proved that the hotel industry is a priority in the development of tourism in most regions of Ukraine. In the region, the hotel industry performs an infrastructural function and allows the traveler to move into the category of a tourist, which to stay in the region for a longer time and spend more money.

It is proved that the hospitality sphere in the region is formed under the influence of a number of factors. Such factors include: development of tourist infrastructure, availability of attractive tourist facilities in the region; development of 
Економічні науки: збірник наукових праць Луцького національного технічного університету. Серія "Регіональна економіка". Випуск 18 (71). Редкол.: відп. ред. д.е.н., професор Л.Л. Ковальська. Луцьк: ІВВ Луцького НТУ, 2021. 278 с.

institutional support for the activities of hospitality entities, the volume of tourist flows, the promotion of the region as a tourist, interesting and safe place for tourists, the availability of qualified personnel in the hospitality industry, etc.

The international experience of hotel industry development is studied. It was found out that today Ukraine occupies one of the last places among the world's countries, especially European ones, in terms of quantitative and qualitative indicators of hotel development. Quantitatively, there are 27 thousand inhabitants per 1 hotel in Ukraine, while in the Czech Republic - 2.3 thousand, Estonia - 3.4 thousand, Bulgaria - 3.9 thousand.

The regional factors of development of competitive advantages of hotel economy (seasonality, specialization of hotel economy in region (tourist, resort, business, level of safety of region), availability of the developed tourist infrastructure, qualification of personnel of hotel economy, range of hotel services in region, complexity are defined regional tourism product, etc) It is proven that competitive advantage is beneficial, it must meet the requirements: to distinguish the hotel industry; to ensure a long-term market position; to meet the relevant modern needs of consumers; to build on available resources; changes in the market environment, to be formed at the strategic level, taking into account the interaction of all stakeholders.

Key words: competitive advantages, hotel industry, hospitality industry.

Смаль Б.А.

\section{РЕГИОНАЛЬНЫЕ АСПЕКТЫ РАЗВИТИЯ КОНКУРЕНТНЫХ ПРЕИМУЩЕСТВ ИНДУСТРИИ ГОСТЕПРИИМСТВА}

В статье исследованы региональные основы развития гостиничного хозяйства в Украине. Определены содержание и значение гостиничного хозяйства в структуре регионального развития индустрии гостеприимства. Проанализирован международный опыт развития гостиничного хозяйства. Проведен анализ развития гостиничного хозяйства в динамике и региональном разрезе. Систематизированы конкурентные преимущества гостиничного хозяйства в регионах Украины. Предложены направления развития конкурентных преимуществ гостиничного хозяйства.

Ключевые слова: конкурентные преимущества, гостиничное хозяйство, индустрия гостеприимства.

Постановка проблеми у загальному вигляді та ії зв'язок 3 важливими науковими та практичними завданнями. Поширення пандемії в Україні та світі, процес глобалізації світової економіки, загострення конкуренції, нестабільність політичної та економічної ситуації, мінливість 
Економічні науки: збірник наукових праць Луцького національного технічного університету. Серія "Регіональна економіка". Випуск 18 (71). Редкол.: відп. ред. д.е.н., професор Л.Л. Ковальська. Луиьк: ІВВ Луиького НТУ, 2021. 278 с.

зовнішнього середовища $є$ ключовими факторами, які впливають на індустрію гостинності [1]. Останнім часом, індустрія гостинності зазнала серйозних втрат, найбільші збитки були характерні для готельного господарства. Зазначене зумовлює пошук оптимальних шляхів розвитку конкурентних переваг індустрії гостинності в регіонах, а саме конкурентних переваг готельного господарства відповідно до міжнародних стандартів та кращих світових практик.

Аналіз останніх досліджень, у яких започатковано вирішення проблеми. Значну увагу щодо дослідження проблем конкурентоспроможності індустрії гостинності, підвищення iіi рівня та формування конкурентних переваг на різних ієрархічних рівнях досліджуваної індустрії, здійснили українські та зарубіжних вчені, такі як: Горіна Г., Данилова О., Зайцева В., Ковальчук Т., Лупич О., Підвальна О., Сідина Л., Тітомир Л., Юхновська Ю. та ін. Проте процеси підвищення конкурентоспроможності готельного господарства на рівні регіону не знайшли достатнього висвітлення в працях, а тому потребують подальших досліджень.

Цілі статті. Метою дослідження є наукове обгрунтування можливих шляхів підвищення конкурентоспроможності готельного господарства в регіонах України на основі визначення його ролі в індустрії гостинності регіону, здійсненні аналізу регіонального розвитку готельного господарства, а також огляду міжнародного досвіду досліджуваних процесів.

Виклад основного матеріалу дослідження 3 повним обгрунтуванням отриманих наукових результатів. Готельне господарство $є$ однією 3 основних складових як індустрії гостинності так і соціально-економічного розвитку більшості регіонів. До виникнення пандемії COVID-19, індустрія гостинності у світі розвивалась доволі швидкими темпами [5].

Індустрію гостинності регіону розглядаємо як системне утворення в регіоні, яке є відносно регульоване, відкрите, характеризується рядом складових елементів (колективні засоби розміщення, гастрономія, туристична галузь, івентивна індустрія тощо), що визначає мультиплікативність системи та 
Економічні науки: збірник наукових праць Луцького національного технічного університету. Серія "Регіональна економіка". Випуск 18 (71). Редкол.: відп. ред. д.е.н., професор Л.Л. Ковальська. Луиьк: ІВВ Луцьккого НТУ, 2021. 278 с.

складність взаємозв'язків між суб'єктами цієї системи. В регіоні індустрія гостинності формується під впливом ряду факторів, основними серед яких, на нашу думку, є [2]:

- туристична інфраструктура;

- наявність атрактивних туристичних об'єктів;

- інституційне забезпечення діяльності суб'єктів гостинності регіону;

- обсяг туристичних потоків, кількість надходжень;

- промоція туристичного потенціалу регіону;

- кваліфіковані кадри сфери гостинності тощо.

Схематичне зображення місця готельного господарства у структурі регіонального розвитку сфери гостинності сформовано на рис. 1.

Готельне господарство є пріоритетним напрямом розвитку туризму більшості регіонів України. На рівні регіону, готельне господарство виконує інфраструктурну функцію та дозволяє подорожуючому перейти в категорію туриста, тобто залишитись в регіоні на довший час та потратити більше коштів (рис. 1). Внесок туризму в соціально-економічний розвиток регіону визначається кількістю витрачених коштів туристами, саме готельне господарство дозволяє та стимулює туристів затриматись довше в регіоні та лишити більше коштів, купуючи регіональні товари та послуги. Крім розміщення туристів, готельне господарство забезпечує реалізацію ряду базових потреб людини [3].

Спеціалізована інфраструктура регіону, що представлена окрім готельного господарства, ресторанними закладами та індустрією розваг і подій в регіоні також є визначальною для розвитку конкурентних переваг регіону. Готельне господарство в даному аспекті є визначальним. 
Економічні науки: збірник наукових пращь Луцького національного технічного університету. Серія "Регіональна економіка". Випуск 18 (71). Редкол.: відп. ред. д.е.н., професор Л.Л. Ковальська. Луцьк: ІВВ Луцького НТУ, 2021. 278 с.

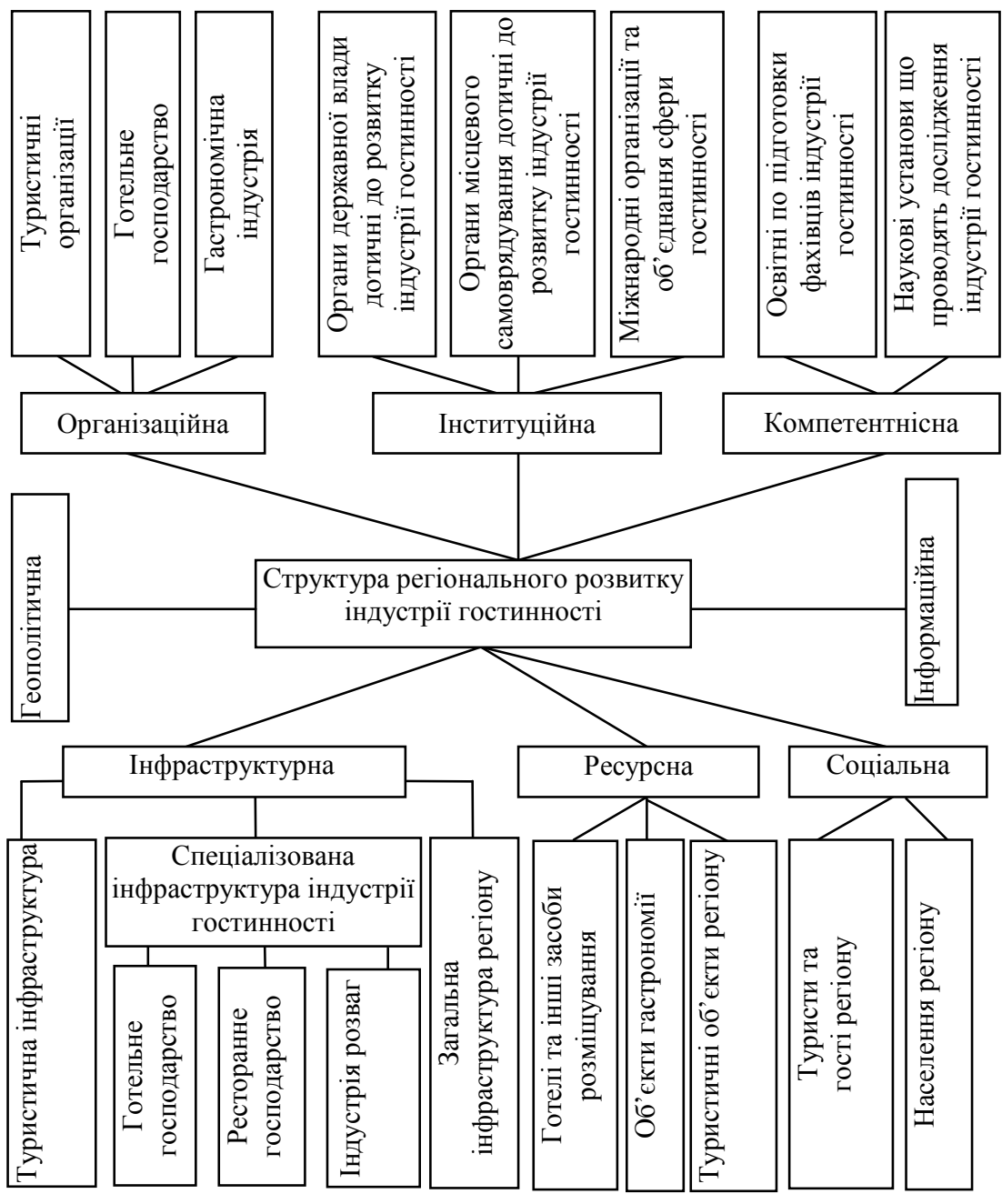

Рис. 1. Роль готельного господарства в структурі регіонального розвитку індустрії гостинності.

Готельне господарство відіграє важливу роль у розвитку регіонів, підвищуючи їх конкурентні переваги, стимулюючи їх соціально-економічний розвиток, надаючи місцевому 
Економічні науки: збірник наукових праць Луцького національного технічного університету. Серія "Регіональна економіка". Випуск 18 (71). Редкол.: відп. ред. д.е.н., професор Л.Л. Ковальська. Луиьк: ІВВ Луиького НТУ, 2021. 278 с.

населенню робочі місця тощо. Зазначене можливе за умови злагодженої роботи усіх стейкхолдерів розвитку індустрії гостинності в регіоні $[4,9]$.

Дослідження міжнародного досвіду є одним 3 шляхів підвищення конкурентних переваг індустрії гостинності в регіонах України. Україна посідає одне з останніх місць серед світових країн, особливо Свропейських, за кількісними та якісними показниками розвитку готельного господарства. Так кількісно в Україні на 1 готель припадає 27 тис. жителів, тоді як у Чехії - 2,3 тис., Естонії - 3,4 тис., Болгарії - 3,9 тис [10].

Результатами досліджень свідчать про збільшення попиту на готелі категорії люкс. Попит на послуги готелів вищого класу збільшується швидкими темпами. Ключовими критеріями таких готелей $\epsilon$ високий рівень якості послуг та значний їх асортимент, що може задовольнити потреби сучасних гостей [6].

Ринок елітних готелів оцінюється у 82,77 млрд дол. За прогнозами експертів його вартість у 2025 р. становитиме 114,35 млрд дол. Так наприклад, з 2016 по 2018 роки середні витрати на одного туриста зросли на 3,2 \% 322534 до 2700 доларів [8].

Лідером серед країн світу щодо доходу на ринку елітних готельних послуг є США, де цей показник становить 75,5\%. Швидкими темпами розвивається елітна готельна індустрія в Китаї та Індії. Аналіз динаміки розвитку luxury-сервісу на ринку готельних послуг засвідчив також розвиток такої індустрії в Китаї та Індії. Згідно оприлюднених результатів аналітичного звіту компанії Global Data кількість готелів категорії люкс у 2019 р. становила 1067 одиниць, що на 20 одиниць більше, ніж у 2018 році [6].

3 метою підтримки готельної індустрії під час пандемії більшість країн Європейського союзу розробили та запровадили програми підтримки у таких напрямках: [10]

- вплив на ліквідність готельного бізнесу (Латвія, Франція, Греція та Німеччина запровадила знижену ставку податку на додану вартість у 5 \% для готельних підприємств; Швейцарія запровадила мораторій на вимоги клієнтів, що виникають 
Економічні науки: збірник наукових праць Луцького національного технічного університету. Серія "Регіональна економіка". Випуск 18 (71). Редкол.: відп. ред. д.е.н., професор Л.Л. Ковальська. Луиьк: ІВВ Луцьького НТУ, 2021. 278 с.

внаслідок неможливості надати готельну послугу, яка була оплачена; Греція, Італії та ще 18 країн Європейського союзу запровадили спеціальні кредитні лінії для готельного бізнесу);

- створення програми субсидій для місцевого населення на відпочинок (Корея, Німеччина i Швеція надавала своїм працівникам бонуси за відпустку, еквівалентні $25 \%$ вартості відпустки; Японія покривала витрати на готелі протягом перших трьох днів відпочинку);

- інвестиції в цифрові рішення для заміни людських контактів в індустрії гостинності (Франція та Німеччина субсидують автопідприємства, оновлюють свій автопарк електричними автомобілями; більшість країн Свропейського союзу фінансують розробку Інтернет-додатків для бронювання готельних та туристичних послуг) [7].

Зазначене показує зацікавленість урядів більшості країн в розвитку готельного господарства.

Аналіз розвитку готельного господарства засвідчив, що в Україні у 2019 році кількість готелів та аналогічних засобів розміщення, у порівняні 32020 роком була достатньо (1626 одиниць). У 2020 році у порівнянні з 2019 роком кількість готельних господарств зменшилася майже на 283 одиниць. Дані значення досить показово корелюють 3 поширенням деструктивних факторів в регіонах. Найбільша кількість готельних господарств припинила свою діяльність у Одеській області - 40 суб'єктів.

Динаміка розвитку готельного господарства в регіонах України за 2019-2020 роки представлено в таблиці 1.

Таблиця 1

Регіональний розвиток готельного господарства в Україні

\begin{tabular}{|l|c|c|c|c|c|c|}
\hline \multirow{2}{*}{ Регіон } & \multicolumn{3}{c|}{ Кількість суб’єктів } & \multicolumn{3}{c|}{ Кількість місць } \\
\cline { 2 - 7 } & 2019 & 2020 & відхилення & 2019 & 2020 & відхилення \\
\hline Вінницька & 21 & 10 & -11 & 1869 & 1017 & -852 \\
\hline Волинська & 61 & 36 & -25 & 3309 & 1987 & -1322 \\
\hline Дніпропетровська & 106 & 87 & -19 & 13070 & 8047 & -5023 \\
\hline Донецька & 88 & 65 & -23 & 10884 & 7396 & -3488 \\
\hline Житомирська & 19 & 16 & -3 & 1615 & 1193 & -422 \\
\hline Закарпатська & 59 & 48 & -11 & 4672 & 3905 & -767 \\
\hline Запорізька & 133 & 119 & -14 & 17938 & 16169 & -1769 \\
\hline
\end{tabular}


Економічні науки: збірник наукових прачь Луцького національного технічного університету. Серія "Регіональна економіка". Випуск 18 (71). Редкол.: відп. ред. д.е.н., професор Л.Л. Ковальська. Луиьк: ІВВ Луцьккого НТУ, 2021. 278 с.

Продовження таблиці 1

\begin{tabular}{|l|c|c|c|c|c|c|}
\hline Івано-Франківська & 64 & 50 & -3 & 5912 & 5002 & -910 \\
\hline Київська & 96 & 80 & -16 & 10184 & 9910 & -274 \\
\hline Кіровоградська & 37 & 20 & -17 & 2377 & 1223 & -1154 \\
\hline Луганська & 11 & 7 & -4 & 952 & 642 & -310 \\
\hline Львівська & 130 & 111 & -19 & 13188 & 12086 & -11902 \\
\hline Миколаївська & 103 & 83 & -20 & 12081 & 11327 & -754 \\
\hline Одеська & 187 & 147 & -40 & 26151 & 21707 & -4444 \\
\hline Полтавська & 44 & 43 & -1 & 3453 & 3393 & -60 \\
\hline Рівненська & 18 & 13 & -5 & 1588 & 619 & -969 \\
\hline Сумська обл. & 21 & 17 & -4 & 1424 & 1300 & -124 \\
\hline Тернопільська & 15 & 13 & -2 & 1392 & 1269 & -123 \\
\hline Харківська & 73 & 66 & -7 & 7824 & 6698 & -1126 \\
\hline Херсонська. & 88 & 70 & -18 & 16594 & 12582 & -4012 \\
\hline Хмельницька & 31 & 28 & -3 & 2606 & 2078 & -528 \\
\hline Черкаська & 55 & 43 & -12 & 4308 & 3076 & -1232 \\
\hline Чернівецька & 13 & 11 & -2 & 2108 & 1135 & -973 \\
\hline Чернігівська & 24 & 22 & -2 & 1949 & 1391 & -558 \\
\hline м. Київ & 129 & 132 & -3 & 20662 & 19877 & -785 \\
\hline Усього & 1626 & 1337 & -289 & 186840 & 155029 & -31811 \\
\hline
\end{tabular}

Загальна кількість місць у колективних засобах розміщування за регіонами у 2020 році зменшилась, у порівняні 32019 роком, на 31811 одиниць. Найвищий такий показник характерний для Львівської області - 11902 місць у колективних засобах розміщування.

Таким чином, для подолання негативних тенденцій розвитку готельного господарства доцільно розвивати їх конкурентні переваги. Щоб конкурентна перевага приносила користь, вона має відповідати вимогам: вигідно відрізняти готельне господарство регіону, забезпечувати довгострокове положення на туристичному ринку, задовольняти відповідні сучасні потреби споживачів, базуватись на наявних ресурсах, мати інноваційну спрямованість, бути гнучкою, адаптуватися до змін у ринковому середовищі, формуватися на стратегічному рівні з урахуванням взаємодії усіх стейкхолдерів.

Висновки. Узагальнено та визначено роль готельного господарства в структурі регіонального розвитку індустрії гостинності. Доведено, що готельне господарство $\epsilon$ 
Економічні науки: збірник наукових праць Луцького національного технічного університету. Серія "Регіональна економіка". Випуск 18 (71). Редкол.: відп. ред. д.е.н., професор Л.Л. Ковальська. Луиьк: ІВВ Луиького НТУ, 2021. 278 с.

пріоритетним напрямом розвитку туризму більшості регіонів України. В регіоні, готельне господарство виконує інфраструктурну функцію та дозволяє подорожуючому перейти в категорію туриста, тобто залишитись в регіоні на довший час та потратити більше коштів.

Доведено, що в регіоні сфера гостинності формується під впливом ряду факторів. До таких факторів віднесено: розвиток туристичної інфраструктури, наявність атрактивних туристичних об'єктів в регіоні; розвиток інституційного забезпечення діяльності суб'єктів гостинності, обсяг туристичних потоків, промоція регіону, як туристичного, цікавого та безпечного місця для туристів, наявність кваліфікованих кадрів індустрії гостинності тощо.

Досліджено міжнародний досвід розвитку готельного господарства. Вияснено, що сьогодні Україна посідає одне 3 останніх місць серед світових країн, особливо Свропейських, за кількісними та якісними показниками розвитку готельного господарства. Кількісно в Україні на 1 готель припадає 27 тис. жителів, у Чехії - 2,3 тис., Естонії - 3,4 тис., Болгарії - 3,9 тис.

Визначено регіональні фактори розвитку конкурентних переваг готельного господарства (сезонність, спеціалізація готельного господарства в регіоні (туристична, курортна, ділова, рівень безпеки регіону (особливо в час пандемії), наявність розвиненої туристичної інфраструктури, кваліфікація персоналу готельного господарства, асортимент готельних послуг в регіоні, комплексність регіонального туристичного продукту тощо). Доведено, щоб конкурентна перевага приносила користь, вона має відповідати вимогам: вигідно відрізняти готельне господарство; забезпечувати довгострокове положення на ринку; задовольняти відповідні сучасні потреби споживачів; грунтуватися на наявних ресурсах; мати інноваційну спрямованість; бути гнучкими, адаптуватися до змін у ринковому середовищі; формуватися на стратегічному рівні 3 урахуванням взаємодії усіх стейкхолдерів.

\section{Список бібліографічного опису}

1.Горіна Г.О. Стратегічні пріоритети розвитку ринку туристичних послуг України в умовах поглиблення інтеграційних процесів. Вісник 
Економічні науки: збірник наукових праць Луцького національного технічного університету. Серія "Регіональна економіка". Випуск 18 (71). Редкол.: відп. ред. д.е.н., професор Л.Л. Ковальська. Луцьк: ІВВ Луцького НТУ, 2021. 278 с.

Донецького національного університету економіки $і$ торгівлі ім. Михайла Туган-Барановського. Серія : Економічні науки. 2016. №3 (64). С. 103-109.

2.Індустрія гостинності в Україні: стан і тенденції розвитку : монографія / колектив авторів ; за ред. проф. М. Зайцевої ; Запорізький національний технічний університет. Запоріжжя: Просвіта, 2017. 240 с.

3.Ковальчук Т. Г. Перспективи розвитку готельно-ресторанного бізнесу в Україні в умовах глобалізації світового господарства. Науковий вісник Ужгородського національного університету. Серія «Міжнародні економічні відносини та світове господарство». 2019. Вип. 23. Ч. 1. С. 126-130.

4.Лупич О.О. Формування конкурентоспроможного готельного господарства регіону: 08.00.04. Ужгород, 2017. 279 с.

5.Пандемія COVID-19 та її наслідки у сфері туризму в Україні. Режим доступу: http://www.ntoukraine.org/assets/files/EBRD-COVID19-Report-UKR.pdf

6.Перспективи розвитку туризму в Україні та світі: управління, технології, моделі: колект. монографія. за наук. ред. Л. Матвійчук, Ю. Барського, М. Лепкого. Луцьк: РВВ Луцького НТУ. 2021. 360 с.

7.Підвальна О. Фактори розвитку сфери туризму: регіональний аспект. Підприємництво та інновації, (11-2), 2020. 66-71.

8.Сідина Л. П. Перспективи розвитку готельно-ресторанної індустрії України: теорія, практика, інновації розвитку. Інвестиції: практика та досвід. 2019. № 5. C. 58-62.

9.Тітомир Л.А., Данилова О.І. Концептуальні стратегій розвитку готельно-ресторанних підприємств на півдні України. Науковий вісник Херсонського державного університету. 2019. Вип. 33. С. 138-142.

10. Туристичний та готельно-ресторанний бізнес: світовий досвід та перспективи розвитку для України: Матеріали Міжнародної науковопрактичної конференції студентів, аспірантів та вчених, 15 квітня 2020 р.: у 3-х томах. Т. 2. Одеса: Одеський національний економічний університет, 2020. 459 c.

11. Юхновська Ю. О. Дослідження потенціалу туристичної галузі конкурентоздатних регіонів України. Держава та регіони. Серія: Економіка та підприємництво. № 5 (110). 2019. С. 65-70.

\section{References}

1. Gorina G. (2016) Strategic priorities of development of the market of tourist services of Ukraine in the conditions of deepening of integration processes. Bulletin of Donetsk National University of Economics and Trade. Mikhail TuganBaranovsky. Series: Economic Sciences. №3 (64). Pp. 103-109.

2. Hospitality industry in Ukraine: state and development trends: monograph / team of authors; for general ed. prof. V. Zaitseva; Zaporizhia National Technical University. Zaporozhye: Prosvita, 2017. 240 p.

3. Kovalchuk T. (2019) Prospects for the development of hotel and restaurant business in Ukraine in the context of globalization of the world economy. Scientific Bulletin of Uzhhorod National University. Series «International Economic Relations and the World Economy». Issue. 23. Part. 1. P. 126-130. 
Економічні науки: збірник наукових праць Луцького національного технічного університету. Серія "Регіональна економіка". Випуск 18 (71). Редкол.: відп. ред. д.е.н., професор Л.Л. Ковальська. Луцьк: ІВВ Луцького НТУ, 2021. 278 с.

4. Lupich O. (2017) Formation of competitive hotel industry of the region: 08.00.04. Uzhhorod. 279 p.

5. COVID-19 pandemic and its consequences in the field of tourism in Ukraine Access mode http://www.ntoukraine.org/assets/files/EBRD-COVID19Report-UKR.pdf

6. Prospects for tourism development in Ukraine and the world: management, technology, models: collection. Monograph (2021) According to the scientific edition. L. Matviychuk, Yr. Barsku, M. Lepkyj. Lutsk: PD Lutsk NTU. $360 \mathrm{p}$.

7. Basement, O. (2020). Factors of tourism development: regional aspect. Entrepreneurship and Innovation, (11-2), 66-71.

8. Sidina L. (2019) Prospects for the development of the hotel and restaurant industry of Ukraine: theory, practice, innovation. Investments: practice and experience. № 5. P. 58-62.

9. Titomir L., Danilova O. (2019) Conceptual strategies for the development of hotel and restaurant enterprises in southern Ukraine. Scientific Bulletin of Kherson State University. Issue. 33. P. 138-142.

10. Tourism and hotel and restaurant business: world experience and development prospects for Ukraine: Proceedings of the International scientificpractical conference of students, graduate students and scientists, April 15, 2020: in 3 volumes. Vol. 2. Odessa: Odessa National Economic University, 2020. 459 p

11. Yukhnovska Y. (2019) Research of the potential of the tourism industry of competitive regions of Ukraine. State and regions. Series: Economics and Entrepreneurship. № 5 (110). P. 65-70.

DOI: https://doi.org/10.36910/2707-6296-2021-18(71)-19 